\title{
Equilibria and Stability in Glycine, Tartrate and Tryptophan Complexes, Investigation on Interactions in Cu(II) Binary and Ternary Systems in Aqueous Solution
}

\author{
S. A. A. Sajadi \\ Sharif University of Technology, Institute of Water \& Energy, Tehran, Iran \\ Email: sajadi@sharif.ac.ir
}

Received March 4, 2012; revised April 4, 2012; accepted April 11, 2012

Copyright (C 2014 S. A. A. Sajadi. This is an open access article distributed under the Creative Commons Attribution License, which permits unrestricted use, distribution, and reproduction in any medium, provided the original work is properly cited. In accordance of the Creative Commons Attribution License all Copyrights (C) 2014 are reserved for SCIRP and the owner of the intellectual property S. A. A. Sajadi. All Copyright (C) 2014 are guarded by law and by SCIRP as a guardian.

\begin{abstract}
The acidity and stability constants of $\mathrm{M}(\mathrm{Gly})^{1}, \mathrm{M}(\mathrm{Ttr})^{1}$, and $\mathrm{M}(\mathrm{Trp})^{1} \mathrm{M}: \mathrm{Cu}^{2+}, \mathrm{Cu}\left(\mathrm{Bpy}^{2}\right)^{2+}$, and $\mathrm{Cu}\left(\mathrm{Phen}^{3}\right)^{2+} \mathrm{com}^{-}$ plexes, were determined by potentiometric $\mathrm{pH}$ titration. It is shown that the stability of the binary $\mathrm{Cu}(\mathrm{L})$, (L: Gly, Ttr, and Trp) complex is determined by the basicity of the carboxylate group on one side and amino group on the other side. It is demonstrated that the equilibrium, $\mathrm{Cu}\left(\mathrm{Ha}^{4}\right)^{2+}+\mathrm{Cu}(\mathrm{L}) \rightleftharpoons \mathrm{Cu}(\mathrm{Har})(\mathrm{L})+\mathrm{Cu}^{2+}$, is displacement due to the well known experience that mixed ligand complexes formed by a divalent $3 \mathrm{~d}$ ion, a heteroaromatic $N$ base and an $O$ donor ligand possess increased stability. The stability constants of the 1:1 complexes formed between $\mathrm{Cu}^{2+}, \mathrm{Cu}(\mathrm{Bpy})^{2+}$ or $\mathrm{Cu}(\mathrm{Phen})^{2+}$ and $\mathrm{L}^{2-}$, were determined by potentiometric $\mathrm{pH}$ titration in aqueous solution $\left(I=0.1 \mathrm{M}, \mathrm{NaNO}_{3}, 25^{\circ} \mathrm{C}\right)$. The order of the stability constants was reported. A comparative investigation between ternary complexes of Trp, Ttr, and Gly is made. The comparison of stability constants of these ternary complexes show that $\mathrm{Cu}(\mathrm{Har})(\mathrm{Trp})$ is found near $100 \%$ in closed form but $\mathrm{Cu}(\mathrm{Har})(\mathrm{Gly})$ exists in open form. The differences between the above mentioned stability constants are based on stacked form of $\mathrm{Cu}(\mathrm{Har})(\mathrm{Trp})$. The last provides increased stability.
\end{abstract}

\section{KEYWORDS}

Glycine; Tartaric Acid; Tryptophan; Divalent Metal Ions; Potentiometric Titration; Acidity and Stability Constants

\section{Introduction}

The naturally occurring form of the acid is $\mathrm{L}(+)$-tartaric acid $\left(\mathrm{H}_{2} \mathrm{Ttr}\right)$ or dextrotartaric acid (Figure 1). Tartaric acid is found throughout nature, especially in many fruits and wine [1]. It is added to other foods to give a sour taste, and is used as an antioxidant. Salts of tartaric acid are known as tartrates. As a food additive, Tartaric acid is used as an antioxidant with E number E334. Tartrates are other additives serving as antioxidants or emulsifiers. However, Tartaric acid plays an important role chemically, lowering the $\mathrm{pH}$ of fermenting "must" to a level where many undesirable bacteria cannot live, acting as a

${ }^{1}$ Gly: Glycine, Ttr: Tartrate, Trp: L-Tryptophan.

${ }^{2}$ Bpy: 2,2'-Bipyridyl.

${ }^{3}$ Phen: 1,10-phenanthroline.

${ }^{4}$ Har: Heteroaromatic ligand such as Bpy or Phen. preservative after fermentation [2]. Tryptophan (Figure 1) [1] is one of the 20 standard amino acids, as well as an essential amino acid in the human diet. Tryptophan (Trp) is considered exceptional in its diversity of biological functions [2]. It is a vital constituent of proteins and indispensable in human nutrition for establishing and maintaining a positive nitrogen balance [3]. Besides, some of its derivatives are potent drugs [4]. Trp is widely used in food industry. It is sometimes added to dietary and feed products as a food fortifier in order to maintain the amino acid balance of the food and correct possible dietary deficiencies. Trp can also be used to study structure and dynamics of the proteins because of its indole moiety [5]. In particular, Trp is the precursor of the neurotransmitter serotonin and plays an important role in brain function and related regulatory mechanisms [6]. In 


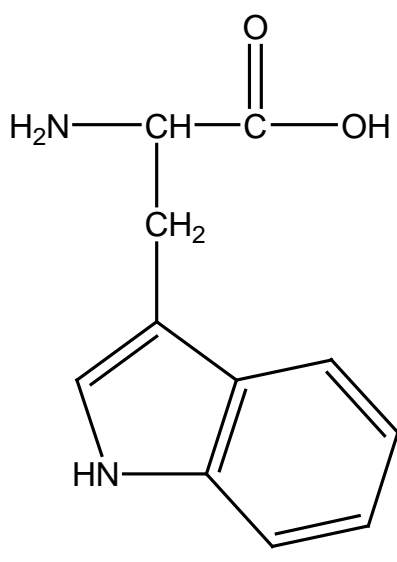

(a)

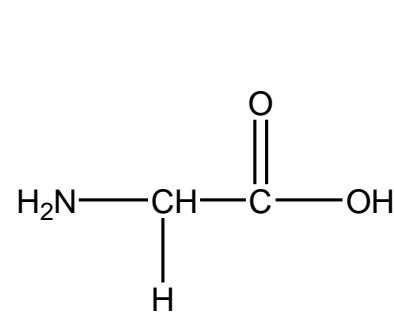

(c)

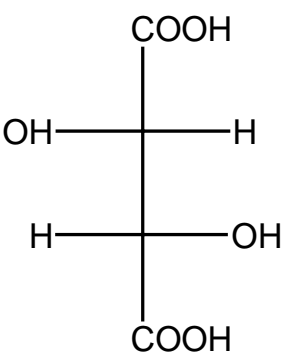

(e)

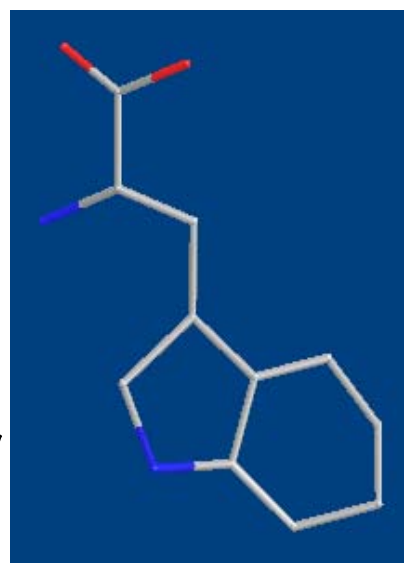

(b)

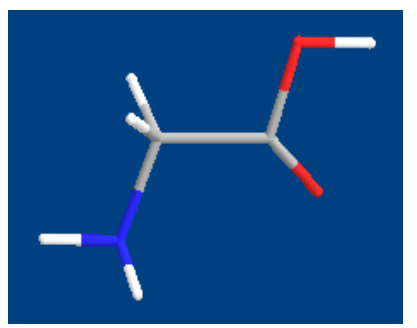

(d)

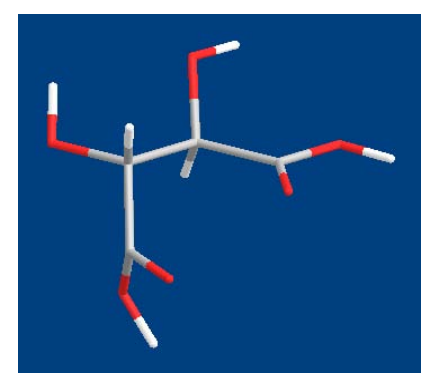

(f)
Figure 1. Chemical formula of L-Tryptophan (a,b), Glycine (c,d), Tartaric acid (e,f). (Description of colors: C: black, $H$ : white, O: red, N: blue).

addition, Trp is an important and frequently used starting material in the chemical synthesis of a range of pharmaceuticals [7].

The importance of noncovalent interactions for the shape of macromolecules, the selectivity in biological system is generally accepted and especially hydrophobic and stacking interactions, which have been considered in mixed ligand complexes [8-10].

The distinguishing structural characteristic of tryptophan is that it contains an indole functional group. It is an essential amino acid as demonstrated by its growth effects on rats. Now it is interesting to investigate the complex bilding of ternary systems with Trp. We would like to determine the thermodynamic constants of ternary complexes such as $\mathrm{Cu}(\mathrm{Har})(\mathrm{L})$. This kind of structure of $\mathrm{L}$ complex can show new aspect of L's properties in biological systems.

\section{Experimental}

\subsection{Materials}

Chemicals were purchased from Merck. Glycine, sodium tartrate, L-tryptophan, copper(II) nitrate trihydrated, sodium nitrate, potassium hydrogen phthalate and standard solutions of sodium hydroxide (titrasol), 2,2'- bipyridyl, 1,10-phenanthroline, nitric acid, EDTA and buffer solutions of $\mathrm{pH} 4.0,7.0$ and 9.0 were from Merck. All the starting materials were pro analysis and used without further purification. Water was purified by Mili-Q water purification system, deionized and distillated.

\section{2. pH Titrations}

Reagents: Carbonate-free sodium hydroxide $0.03 \mathrm{M}$ was preparated and standardized against sodium hydrogen phthalate and a standard solution of nitric acid $0.5 \mathrm{mM}$. Copper (II) nitrate solution (0.03 M) was prepared by dissolving the above substance in water and was standardized with standard solution of EDTA $0.1 \mathrm{M}$ (triplex).

\subsection{Apparatus}

All pH titrations was performed using a Metrohm 794 basic automatic titrator (Titrino), coupled with a Hero thermostating bath at $25^{\circ} \mathrm{C}\left( \pm 0.1^{\circ} \mathrm{C}\right)$ and a Metrohm combined glass electrode $(\mathrm{Ag} / \mathrm{AgCl})$. The $\mathrm{pH}$ meter was calibrated with Merck standard buffer solutions (4.0, 7.0 and 9.0).

\subsection{Procedure}

For the determination of acid dissociation constants of the ligand $\mathrm{L}$ an aqueous solution $(0.3 \mathrm{mM})$ of the protonated ligand was titrated with $0.03 \mathrm{M} \mathrm{NaOH}$ at $25^{\circ} \mathrm{C}$ under nitrogen atmosphere and ionic strength of $0.1 \mathrm{M}$, $\mathrm{NaNO}_{3}$. For the determination of binary (one ligand and $\left.\mathrm{Cu}^{2+}\right)$ and ternary systems $\left(\mathrm{Cu}^{2+}\right.$, one of the other $\mathrm{L} \mathrm{li-}$ gand (Har) and L), the ratios used were $1: 1: 1, \mathrm{Cu}(\mathrm{II}): \mathrm{L}$ : Har, $0.3 \mathrm{mM}$. This solution was titrated with $0.03 \mathrm{M}$ $\mathrm{NaOH}$ under the same conditions mentioned above. Each titration was repeated seven times in order to check the reproducibility of the data.

\subsection{Calculation}

The acid dissociation constants, $K_{H_{2}(L)}^{H}$ and $K_{H(L)}^{H}$ for $\mathrm{H}_{2}(\mathrm{~L})$ were calculated by an algebraic method. The equilibria involved in the formation of 1:1 complex of $\mathrm{L}$ and a $\mathrm{M}\left(\mathrm{Cu}^{2+}, \mathrm{Cu}(\mathrm{Bpy})^{2+}\right.$, and $\left.\mathrm{Cu}(\mathrm{Phen})^{2+}\right)$ may be expressed as Equations (3) \& (4).

\section{Results and Discussion}

\subsection{Acidity Constants}

Ligand (L) can accept one proton on carboxylic group, 
for which the following deprotonation equilibria hold:

$$
\begin{gathered}
\mathrm{H}_{2}(\mathrm{~L}) \rightleftharpoons \mathrm{H}^{+}+\mathrm{H}(\mathrm{L})^{-} \\
\mathrm{K}_{\mathrm{H}_{2}(\mathrm{~L})}^{\mathrm{H}}=\left[\mathrm{H}(\mathrm{L})^{-}\right]\left[\mathrm{H}^{+}\right] /\left[\mathrm{H}_{2}(\mathrm{~L})\right]
\end{gathered}
$$

$\mathrm{L}$ can release one other proton from amine group according following deprotonation equilibria:

$$
\begin{gathered}
\mathrm{H}(\mathrm{L})^{-} \rightleftharpoons \mathrm{H}^{+}+\mathrm{L}^{2-} \\
\mathrm{K}_{\mathrm{H}(\mathrm{L})}^{\mathrm{H}}=\left[\mathrm{L}^{2-}\right]\left[\mathrm{H}^{+}\right] /\left[\mathrm{H}(\mathrm{L})^{-}\right]
\end{gathered}
$$

Also the two protons in $\mathrm{H}_{2}(\mathrm{~L})$ are certainly bound at the terminal acetate group and amine group, i.e., it is released from $-\mathrm{CO}_{2} \mathrm{H}$ or $-\mathrm{NH}_{2}$ according to equilibrium (1) \& (2). These values are, as accepted, close to the $\mathrm{pK}_{\mathrm{a}}$ values of $-\mathrm{CO}_{2} \mathrm{H}$ which is 2.22 [8].

\subsection{Stability of Binary and Ternary Complexes}

If we abbreviate for simplicity $\mathrm{Cu}^{2+}, \mathrm{Cu}(\mathrm{Bpy})^{2+}$, and $\mathrm{Cu}(\mathrm{Phen})^{2+}$ with $\mathrm{M}^{2+}$, one may write the following two equilibria (3) \& (4):

$$
\begin{gathered}
\mathrm{M}^{2+}+\mathrm{H}(\mathrm{L})^{-} \rightleftharpoons \mathrm{M}(\mathrm{H} ; \mathrm{L})^{+} \\
\mathrm{K}_{\mathrm{MH}(\mathrm{L})}^{\mathrm{M}}=\left[\mathrm{M}(\mathrm{H} ; \mathrm{L})^{+}\right] /\left[\mathrm{M}^{2+}\right]\left[\mathrm{H}(\mathrm{L})^{-}\right] \\
\mathrm{M}^{2+}+(\mathrm{L})^{2-} \rightleftharpoons \mathrm{M}(\mathrm{L}) \\
\mathrm{K}_{\mathrm{M}(\mathrm{L})}^{\mathrm{M}}=[\mathrm{M}(\mathrm{L})] /\left[\mathrm{M}^{2+}\right]\left[(\mathrm{L})^{2-}\right]
\end{gathered}
$$

The experimental data of the potentiometric $\mathrm{pH}$ titrations may be completely by considering the above mentioned equilibria (1) through (4), if the evaluation is not carried into the $\mathrm{pH}$ range where hyrdoxo complex formation occurs.

The stability of ternary complexes may be evaluated by the following equilibrium:

$$
\mathrm{mA}+\mathrm{nB}+\mathrm{qM}+\mathrm{rH} \rightleftharpoons \mathrm{A}_{\mathrm{m}} \mathrm{B}_{\mathrm{n}} \mathrm{M}_{\mathrm{q}} \mathrm{H}_{\mathrm{r}}
$$

where $\mathrm{M}$ is the metal ion, $\mathrm{H}$ is the proton, $\mathrm{A}$ and $\mathrm{B}$ are the ligands. The global stability constants for the ternary complexes may be represented as following:

$$
\log \beta_{\text {pqrs }}=\left[\mathrm{A}_{\mathrm{m}} \mathrm{B}_{\mathrm{n}} \mathrm{M}_{\mathrm{q}} \mathrm{H}_{\mathrm{r}}\right] /[\mathrm{A}]^{\mathrm{m}}[\mathrm{B}]^{\mathrm{n}}[\mathrm{M}]^{\mathrm{q}}[\mathrm{H}]^{\mathrm{r}}
$$

It is possible to define the stability constants for ternary complexes in relation to their binary ones [9], represented by the equilibrium (6) \& (7).

$$
\begin{gathered}
\mathrm{M}+\mathrm{L}_{1} \rightleftharpoons \mathrm{ML}_{1} \\
\mathrm{~K}_{\mathrm{M}\left(\mathrm{L}_{1}\right)}^{\mathrm{M}}=\left[\mathrm{ML}_{1}\right] /\left[\mathrm{M}^{2+}\right]\left[\mathrm{L}_{1}\right] \\
\mathrm{ML}_{1}+\mathrm{L}_{2} \rightleftharpoons \mathrm{ML}_{1} \mathrm{~L}_{2} \\
\mathrm{~K}_{\mathrm{M}\left(\mathrm{L}_{1} \mathrm{~L}_{2}\right)}^{\mathrm{M}}=\left[\mathrm{ML}_{1} \mathrm{~L}_{2}\right] /\left[\mathrm{ML}_{1}\right]\left[\mathrm{L}_{2}\right]
\end{gathered}
$$

Differences between the stability constants of the ternary and binary complexes show the tendency of the formation of ternary species [10]. This could be expected by Equation (8):

$$
\begin{aligned}
\Delta \log \mathrm{K} & =\log \mathrm{K}_{\mathrm{M}_{1}\left(\mathrm{~L}_{1} \mathrm{~L}_{2}\right)}^{\mathrm{ML}_{1}}-\log \mathrm{K}_{\mathrm{M}\left(\mathrm{L}_{2}\right)}^{\mathrm{M}} \\
& =\log \mathrm{K}_{\mathrm{M}\left(\mathrm{L}_{1} \mathrm{~L}_{2}\right)}^{\mathrm{ML}_{2}}-\log \mathrm{K}_{\mathrm{M}\left(\mathrm{L}_{1}\right)}^{\mathrm{M}}
\end{aligned}
$$

The difference between the constant refined from experimental data and those calculated statistically using Equation (8) indicates the possibility of ligand-ligand interaction.

\subsection{Potentiometric Analyses}

The model of species for these ternary systems that was used in superquad program includes all the species of Table 1 as well as the hydrolysis of $\mathrm{Cu}^{2+}[11,12]$. The stability constants of the binary complexes were refined separately using the titration data of this system in a 1:1 and 1:2 ligand: $\mathrm{Cu}^{2+}$ ratio in the same conditions of temperature and ionic strength. They were fixed and, consequently, only ternary species were refined in ternary model of the species. The results are summarized in Table 1. The order of the resulted stability constants are $\mathrm{Cu}^{2+}<$ $\mathrm{Cu}(\mathrm{Bpy})^{2+}<\mathrm{Cu}(\mathrm{Phen})^{2+}$. Figure 2 shows schematic structures of the species with interactions according to equilibrium (4) \& (7) for $\mathrm{Cu}$ (Phen)(Trp) and $\mathrm{Cu}($ Phen)(Ttr). The results of the acidity constants show good agreement with reported values [13]. The reported stability constant of $\mathrm{Cu}(\mathrm{L})$ complex is similar to our results (Table 1 ). The difference between stability constants according Equation (8) show that mixed ligand complexes [14-17] formed by a divalent $3 \mathrm{~d}$ ion, a heteroaromatic $\mathrm{N}$ base and an $\mathrm{O}$ donor ligand possess increased stability. Now one can calculate the free energy $\Delta \mathrm{G}$, used $\Delta \log \mathrm{K}$ received from Equation 8 (Table 1). We receive for $\Delta \log \mathrm{K}_{\mathrm{Cu}(\mathrm{Bu})(\mathrm{Bpy})(\mathrm{T})}$ $5.44 \mathrm{~kJ} / \mathrm{mol}$ and for $\Delta \log \mathrm{K}_{\mathrm{Cu}(\mathrm{Cu} \text { (Phen)(Trp) }} 7.34 \mathrm{~kJ} / \mathrm{mol}$, which are considerable high. This means that interaction between $\mathrm{Cu}(\mathrm{Har})^{2+}$ and $\mathrm{L}^{2-}$ is relative strong and the observed increased stability indicate strong complex bilding of ternary systems.

It has to be further emphasized that the basicity of the carboxylate group in aqueous solution is very low and consequently this also applies for the coordinating properties of this group.

Comparison of the stability constants for the $\mathrm{Cu}(\mathrm{Bpy})(\mathrm{L})$ and $\mathrm{Cu}(\mathrm{Phen})(\mathrm{L})$ complexes in Table 1 with the corresponding values for $\mathrm{Cu}(\mathrm{L})$ indicates an increased stability of the mixed-ligand species. As it is well known for a number of $\mathrm{Cu}(\mathrm{Har})(\mathrm{L})$ complexes that an increased complex stability is connected with the formation of intramolecular stack between the aromatic ring systems of 2,2'-Bipyridyl and 1,10-phenanthroline and the heteroaromatic ring of $\mathrm{L}$ (opened form $\leftrightarrow$ closed 
Table 1. Acidity constants of Ttr, Trp, Gly. Logarithm of the stability constants of binary and ternary complexes of $\mathrm{M}^{2+}$ at $25^{\circ} \mathrm{C}, 0.1 \mathrm{M}, \mathrm{NaNO}_{3}{ }^{*}$.

\begin{tabular}{|c|c|c|c|c|}
\hline & \multicolumn{2}{|c|}{$\mathrm{pK}_{\mathrm{H}_{2}(\mathrm{Tr})}^{\mathrm{H}}=3.09 \pm 0.07$} & \multicolumn{2}{|c|}{$\mathrm{pK}_{\mathrm{H}(\mathrm{Tr})}^{\mathrm{H}}=4.19 \pm 0.05$} \\
\hline & $\mathrm{pK}_{\mathrm{H}_{2}(\mathrm{Trp})}^{\mathrm{H}}=2.22$ & 0.08 & $\mathrm{pK}_{\mathrm{H}(\mathrm{TP})}^{\mathrm{H}}=$ & 0.03 \\
\hline & $\mathrm{pK}_{\mathrm{H}_{2}(\mathrm{Gl}) \mathrm{f}}^{\mathrm{H}}=2.49$ & 0.08 & $\mathrm{pK}_{\mathrm{H}(\mathrm{Gly})}^{\mathrm{H}}$ & $=0.03$ \\
\hline No. & Species & $\log K^{a}$ & $\Delta \log K^{b}$ & Ref. \\
\hline 1 & $\mathrm{Cu}(\mathrm{Ttr})$ & $3.65 \pm 0.07$ & - & - \\
\hline 2 & Cu(Phen)(Ttr) & $3.92 \pm 0.08$ & $0.27 \pm 0.13$ & - \\
\hline 3 & Cu(Trp) & $8.05 \pm 0.05$ & - & [13] \\
\hline 4 & Cu(Bpy)(Trp) & $9.02 \pm 0.06$ & $0.97 \pm 0.08$ & - \\
\hline 5 & Cu(Phen)(Trp) & $9.36 \pm 0.08$ & $1.31 \pm 0.09$ & - \\
\hline 6 & $\mathrm{Cu}(\mathrm{Gly})$ & $7.06 \pm 0.08$ & - & [18] \\
\hline 7 & Cu(Bpy)(Gly) & $5.95 \pm 0.08$ & $-1.11 \pm 0.11$ & [18] \\
\hline 8 & Cu(Phen)(Gly) & $6.12 \pm 0.07$ & $-0.94 \pm 0.11$ & [18] \\
\hline
\end{tabular}

*The given errors are three times the standard error of the mean value or the sum of the propabable systematic errors, according Equation (4), baccording to Equation (8).

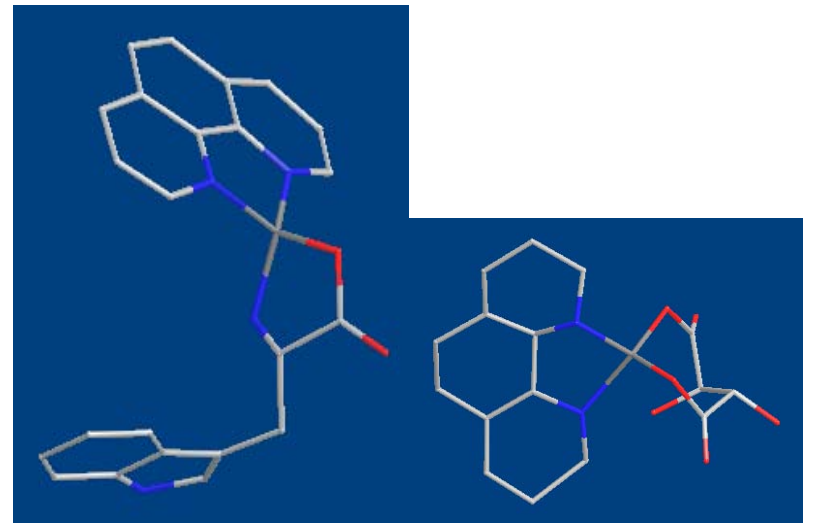

Figure 2. Schematic structures of the species with interactions according to equilibrium (4) \& (7) for $\mathrm{Cu}$ (Phen)(Trp) left and $\mathrm{Cu}$ (Phen)(Ttr) right. The structure in the right part of the figure was drawn with the program CS Chem 3D, version 3.5, from Cambridge Software Corporation. (Description of colors: C: black, O: red, N: blue, Cu: gray).

form) [10]. The difference between the determined stability constants indicate the experimentally ligand-ligand stack interaction in the $\mathrm{Cu}(\mathrm{Har})(\mathrm{L})$ complexes.

As we can see from the experimentally results from Table 1, there is no increased stability constants in case of $\mathrm{Cu}(\mathrm{Har})(\mathrm{Gly})$, this means that there is no indication of intramolecular stack interactions. For this reason we can use the stability constants of $\mathrm{Cu}(\mathrm{Har})(\mathrm{Gly})$ as opened form in our next calculations.

By employing Equation (8) the following definition is possible (Equation (9)):

$$
\begin{aligned}
\Delta \Delta \log \mathrm{K} & =\Delta \log \mathrm{K}_{\mathrm{c} 1}-\Delta \log \mathrm{K}_{\mathrm{op}} \\
& =\Delta \log \mathrm{K}_{\mathrm{Cu}(\text { Phen)(L) }}-\Delta \log \mathrm{K}_{\mathrm{Cu}(\text { Phen)(Gly })}
\end{aligned}
$$

It is evident that the coordination sphere of $\mathrm{Cu}^{2+}$ ions on both sides of this equilibrium are identical, consequently the value for $\Delta \Delta \operatorname{logK}$ is a true reflection of the extent of the intramolecular hydrophobic or stacking interaction in $\mathrm{Cu}(\mathrm{Har})(\mathrm{L})$ complexes. The corresponding results are listed in the fourth column of Table 2.

Now we can define the intramolecular and thus dimensionless equilibrium constant $\mathrm{K}_{I}$ is than given by equation (10) for opened and closed form:

$$
\mathrm{K}_{\mathrm{I}}=[\mathrm{Cu}(\text { Phen })(\mathrm{L})] /[\mathrm{Cu}(\text { Phen })(\mathrm{L})]_{\mathrm{op}}
$$

The observed increased complex stability is linked to $\mathrm{K}_{I}$ by Equation (11):

$$
\mathrm{K}_{\mathrm{I}}=10^{\Delta \Delta \log \mathrm{K}}-1
$$

Knowledge of $K_{I}$ allows calculation of percentage of the macrochelated form according to Equation (12) [10]:

$$
\% \mathrm{Cu}(\operatorname{Har})(\mathrm{L})=100 * \mathrm{~K}_{\mathrm{I}} /\left(1+\mathrm{K}_{\mathrm{I}}\right)
$$

The results of the calculations of above mentioned equations are summarized in Table 2.

Comparison of the percentage of the macrochelated form according to Equation (12) in Table 2 shows the high stacKing tendency of Trp based on heteroaromatic structure of indole moiety [5].

The distinguishing structural characteristic of tryptophan is that it contains an indole functional group. It is an essential amino acid as demonstrated by its growth effects on rats. Now it is interesting to investigate the complex building of ternary systems with Trp. The comparison of stability constants of these ternary complexes show that $\mathrm{Cu}(\mathrm{Har})(\mathrm{Gly})$ exists in open form but $\mathrm{Cu}(\mathrm{Har})(\mathrm{Trp})$ is found near $100 \%$ in closed form (see last column in Table 2). The differences between the stability constants are based on stacked form of $\mathrm{Cu}(\mathrm{Har})(\mathrm{Trp})$. The last provides increased stability. The results described in this study show that Trp is a very versatile ligand. Due to the dominating conformation in aqueous solution, hardly any macrochelates are formed in $\mathrm{Cu}(\mathrm{Har})$ (Trp) complexes. The energy differences between closed and open form in $\mathrm{Cu}(\mathrm{Har})(\mathrm{Trp})$ are significant. One can calculate the free energy $\Delta \mathrm{G}$ for $\mathrm{Cu}(\mathrm{Har})(\mathrm{Trp})$. So we receive respectively values for $\mathrm{Cu}(\mathrm{Bpy})(\mathrm{Trp})$ and $\mathrm{Cu}(\mathrm{Phen})(\operatorname{Trp}) 11.66 \mathrm{~kJ} / \mathrm{mol}$ and $12.62 \mathrm{~kJ} / \mathrm{mol}$. The according structure of ternary $\mathrm{Cu}$ (Phen)(Trp) is shown in Figure 2. Due to the fact that the resulting data is very interesting, that affects the ternary complexes of Trp in biological systems as active. This might be used, for example in the case of cell separation.

The stability constant of the binary complex was refined separately in the same conditions of temperature and ionic strength. It was in good agreement with reported value [9-14]. Figure 2 shows schematic structures of the species with interactions according to equilibrium (4) \& (7) for $\mathrm{Cu}($ Phen)(Trp). 
Table 2. Extent of intramolecular stack formation in ternary $\mathrm{Cu}(\mathrm{Har})(\mathrm{L})$ complexes as calculated from stability constants (Equation (7)). Intramolecular and dimensionless equilibrium constant $\mathrm{K}_{I}$ (Equation (9)) and percentage of stacked $\mathrm{Cu}(\mathrm{Har})(\mathrm{L})_{\mathrm{cl}} \mathrm{species}$ in aqueous solution at $25^{\circ} \mathrm{C}, 0.1 \mathrm{M}, \mathrm{NaNO}_{3}{ }^{*}$.

\begin{tabular}{cccccc}
\hline No. & Species $^{\mathbf{a}}$ & $\Delta \mathbf{l o g} \mathbf{K}^{\mathbf{b}}$ & $\Delta \Delta \mathbf{l o g} \mathbf{K}^{\mathbf{c}}$ & $\mathbf{K}_{\mathbf{I}}^{\mathbf{d}}$ & $\boldsymbol{\%}_{\mathbf{C u}(\mathbf{H a r})(\mathbf{L})_{\mathbf{c l}}{ }^{\mathbf{e}}}$ \\
\hline 1 & $\mathrm{Cu}($ Bpy)(Trp) & $0.97 \pm 0.08$ & $2.08 \pm 0.14$ & $119.23 \pm 38.76$ & $99.17 \pm 0.27$ \\
2 & $\mathrm{Cu}($ Phen)(Trp) & $1.31 \pm 0.09$ & $2.25 \pm 0.14$ & $176.83 \pm 57.34$ & $99.44 \pm 0.18$ \\
3 & $\mathrm{Cu}$ (Bpy)(Gly) & $-1.11 \pm 0.11$ & - & - & - \\
4 & $\mathrm{Cu}$ (Phen)(Gly) & $-0.94 \pm 0.11$ & - & - & - \\
\hline
\end{tabular}

* The given errors are three times the standard error of the mean value or the sum of the propabable systematic errors. ${ }^{\mathrm{a}}$ from Table $\mathbf{1}$, ${ }^{\mathrm{b}}$ according Equation (8), caccording Equation (9), ${ }^{\mathrm{d}}$ according Equation (11), ${ }^{\mathrm{e}}$ according Equation (12).

As we can use from the results in Table 1 , the corresponding value for $\Delta \log \mathrm{K}_{\mathrm{Cu}(\mathrm{Phen})(\mathrm{Tr} r)}=0.27 \pm 0.13$ is relatively high compared with $\Delta \log \mathrm{K}_{\mathrm{Cu}(\text { Phen)(Gly) }}=-0.94 \pm$ 0.11 . The reason for this increased value of $\Delta \log$ $\mathrm{K}_{\mathrm{Cu}(\mathrm{Phen})(\mathrm{Trr})}$ is the involved functional site, such as two carboxyl groups of Ttr in $\mathrm{Cu}(\mathrm{Phen})(\mathrm{Ttr})$ complex, compared with one carboxyl- and one amine groups of Gly in $\mathrm{Cu}(\mathrm{Phen})(\mathrm{Gly})$. It is important for the coordination capability of $\mathrm{Cu}(\mathrm{Phen})(\mathrm{L})$ complexes, whether the entering ligands O- or N-groups offer. The structure of the ternary complex $\mathrm{Cu}(\mathrm{Phen})(\mathrm{Ttr})$ has been shown in Figure 2.

\section{REFERENCES}

[1] IUPAC-IUBMB Joint Commission on Biochemical Nomenclature, "Recommendations on Organic \& Biochemical Nomenclature, Symbols \& Terminology etc.,” 2007. http://www.chem.qmul.ac.uk/iupac/AminoAcid/

[2] A. C. Moffat, J. V. Jackson, M. S. Moss and B. Widdop, "Clarke's Isolation and Identification of Drugs," The Pharmaceutical Press, London, 1986, p. 1056.

[3] A. R. Fiorucci and E. T. G. Cavalheiro, "The Use of Carbon Paste Electrode in the Direct Voltammetric Determination of Tryptophan in Pharmaceutical Formulations," Journal of Pharmaceutical and Biomedical Analysis, Vol. 28, 2002, pp. 909-915.

http://dx.doi.org/10.1016/S0731-7085(01)00711-7

[4] H. H. Hussey, “Sleep Inducement by L-Tryptophan,” Journal of the American Chemical Society, Vol. 87, 1974, p. 1126.

[5] P. Cioni and G. B. Strambini, "Tryptophan Phosphorescence and Pressure Effects on Protein Structure,” Biochimica et Biophysica Acta, Vol. 1595, 2002, pp. 116-130. http://dx.doi.org/10.1016/S0167-4838(01)00339-9

[6] Y. D. Liang and J. F. Song, "Flow-Injection Chemiluminescence Determination of Tryptophan through Its Peroxidation and Epoxidation by Peroxynitrous Acid," Journal of Pharmaceutical and Biomedical Analysis, Vol. 38, 2005, pp. 100-106.

http://dx.doi.org/10.1016/j.jpba.2004.12.010

[7] K. D. Altria, P. Harkin and M. G. Hindson, “Quantitative Determination of Tryptophan Enantiomers by Capillary Electrophoresis," Journal of Chromatography B: Biomedical Sciences and Applications, Vol. 686, 1996, pp. 103-
110. http://dx.doi.org/10.1016/S0378-4347(96)00037-0

[8] Handbook of Chemistry \& Physics, Vol. 55, 1975, p. 129.

[9] J. L. Miranda and J. Felcman, "Study on Guanidino-Carboxylate Interactions in Copper(II) Ternary Complexes of Guanidinoacetic Acid with Glutamic and Aspartic Acids,” Polyhedron, Vol. 22, No. 2, 2003, pp. 225-233. http://dx.doi.org/10.1016/S0277-5387(02)01304-9

[10] S. A. A. Sajadi, B. Song and H. Sigel, “Ternary Complexes in Solution. Intramolecular Stacking Interactions in Mixed Ligand Complexes Formed by Copper(II), 2,2'-Bipyridyl or 1,10-Phenanthroline and a Pyrimidine-Nucleoside 5'-Diphosphate (CDP3-, UDP3-, dTDP3-), ', Inorganica Chimica Acta, Vol. 283, 1998, pp. 193-201. http://dx.doi.org/10.1016/S0020-1693(98)00097-8

[11] J. Felcman and J. L. Miranda, “A Potentiometric Study of Guanidinoacetic Acid Complexation with the Ions Mn(II), Co(II), Ni(II), Cu(II), Zn(II), Cd(II) and Pb(II),” Journal of the Brazilian Chemical Society, Vol. 8, No. 6, 1997, p. 575.

http://dx.doi.org/10.1590/S0103-50531997000600003

[12] L. D. Pettit and A. Powel, "IUPAC Stability Conatants Database, Release 3, Version 3.02,” Academic Software Timble, 1998.

[13] H. Sigel, A. D. Zuberbuehler and O. Yamauchi, “Techniques for Postcolumn Derivatization in Gas Chromatography/Mass Spectrometry,” Analytical Chimistry Acta, Vol. 63, No. 3, 1991, pp. 255-261. http://dx.doi.org/10.1021/ac00003a013

[14] H. Sigel and C. F. Naumann, "Ternary Complexes in Solution. XXIV. Metal Ion Bridging of Stacked Purine- Indole Adducts. The Mixed-Ligand Complexes of Adenosine 5'-Triphospha," Journal of the American Chemical Society, Vol. 98, No. 3, 1976, pp. 730-739. http://dx.doi.org/10.1021/ja00419a015

[15] S. A. A. Sajadi, B. Song and H. Sigel, “Ternary Complexes in Solution. Intramolecular Stacking Interactions in Mixed Ligand Complexes Formed by Copper(II), 2,2'-Bipyridyl or 1,10-Phenanthroline and a Pyrimidine-Nucleoside 5'-Diphosphate (CDP3-, UDP3-, dTDP3-), ,' Inorganica Chimica Acta, Vol. 283, 1998, pp. 193-201.

[16] S. Ali, A. Sajadi, B. Song, F. Gregan and H. Sigel, Bulletin of the Chemical Society of Ethiopia, Vol. 11, No. 2, 1997, pp. 121-130.

[17] S. Ali, A. Sajadi, M. Bastian and H. Sigel, Journal of In- 
organic Biochemistry, Vol. 59, No. 2-3, 1995, p. 139.

[18] S. Ali, A. Sajadi and M. Mirzai, “4th International Con- ference of Drug Discovery \& Therapy,” Dubai, 2013, in press. 